\title{
PENGARUH GOOD CORPORATE GOVERNANCETERHADAP AUDIT REPORT LAG DENGAN KETEPATAN WAKTU PENYAMPAIAN LAPORAN KEUANGAN SEBAGAI VARIABEL MODERASI
}

\author{
B. Anggun Hilendri L, Bambang, Yana Yuliana
}

Fakultas Ekonomi Dan Bisnis Unram

\begin{abstract}
The demand for transparency is quite high since Indonesia is mired in the economic crisis. In fact, this situation is very understandable since a very good level of transparency ascertained the parties' concerned regarding accountability of management. Transparency of the company's financial statement is reflected on the audit and the timeliness of financial reporting.

This study aims to examine the influence of good corporate governance on audit report lag with the timeliness of financial statement submission as a moderation variable. Independent variables used in this study are board of commissioners, independent commissioners, audit committees, and public accounting firms, with timeliness of financial statement submission as the moderating variable, and audit report lag as dependent variable. The population in this research is 100 companies listed in Kompas 100 stock index. Pursuant to purposive sampling technique, this study obtained 84 companies for one year observation, which is the year of 2015.

The result of the study indicate that board of commissioner have negative effect to audit report lag, while independent commissioner, audit committee, and the size of public accounting firm has no influence on audit report lag. The results also show that the timeliness of financial statement submission could not be the moderator on the relationship between board of commissioner, independent commissioner, audit committee, and public accountant firms with audit report lag.

Keywords: board of commissioners, independent commissioners, audit committee, public accountant firms, audit report lag, timeliness, financial statement submission.
\end{abstract}

\section{PENDAHULUAN}

\section{Latar Belakang}

Tuntutan transparansi pada beberapa dekade terakhir cukup tinggi sejak krisis tahun 1990-an. Hal ini dapat dimaklumi karena dengan tingkat 
Bq. Anggun HL, Bambang, E Yana Yuliana: Pengaruh Good Corporate Governance...

transparansi yang sangat baik maka perusahaan akan memperoleh kepercayaan dari pihak yang berkepentingan seperti pemilik atau shareholders, masyarakat umum, regulator atau pemerintah, serta industri lainnya (Sulistyo, 2010). Selain itu reputasi perusahaan juga akan baik dengan adanya kepercayaan dari pihak-pihak tersebut, karena melalui transparansi maka akuntabilitas manajemen dapat dipastikan oleh pemegang saham dan pemangku kepentingan lain (Kumara, 2015). Transparansi (transparency) merupakan bagian dari prinsip-prinsip good corporate governance selain akuntabilitas (accountability), pertanggungjawaban (responsibility), independensi (independency) dan keadilan (fairness) (Komite nasional kebijakan governance, 2006). Sejak Indonesia terperosok dalam krisis ekonomi, maka corporate governance menjadi bagian untuk pembenahan pengelolaan korporasi (Wardhani, 2013).

Selain itu terdapat pola yang berubah menjadi lebih baik dimana fokus perusahaan tidak hanya terkait dengan laba, tetapi juga dituntut untuk memperhatikan people dan planet (Elkington, 1997). Grant (2007) mempunyai sudut pandang lain yaitu equity, ethics and environmental sustainability. Kaitan hal tersebut dengan good corporate governance (GCG) yaitu bahwa aktivitas ekonomi yang dijalankan perusahaan sebagaimana prinsip etika bisnis diharapkan bermanfaat tidak hanya bagi perusahaan itu sendiri, tetapi juga bagi masyarakat. Dengan menerapkan hal tersebut berarti juga memenuhi prinsip responsibilitas yang diusung GCG. Sehingga diperlukan mekanisme agar tujuan-tujuan tersebut terpenuhi secara baik. Hal ini bertujuan untuk mengatur kewenangan direktur, manajer, pemegang saham dan pihak lain yang berhubungan dan berkepentingan dalam perusahaan.

Bentuk transparansi GCG, dilaporkan dalam laporan tahunan bersama laporan keuangan. Laporan keuangan menyajikan informasi yang menyangkut posisi keuangan, kinerja, serta perubahan posisi keuangan suatu perusahaan (SAK 2015: 3). Informasi ini berguna bagi pihak-pihak yang berkepentingan sebagai salah satu input dalam pengambilan keputusan bisnis (Fujianti, 2016). Laporan keuangan harus bersifat transparansi dan relevan sehingga harus disajikan tepat waktu agar informasi laporan keuangan dapat lebih berguna bagi pengguna laporan keuangan (Wijaya, 2012). Pengauditan atas laporan keuangan perlu dilakukan dalam rangka meningkatkan kualitas laporan keuangan tersebut. Hasil audit diharapkan berkualitas melalui proses yang cukup dan mendalam baik dalam hal biaya maupun waktu. Banyaknya prosedur audit yang harus dilakukan seorang auditor dalam mengaudit kliennya membutuhkan waktu yang lama dalam pengerjaannya sehingga hal ini berpengaruh pada lamanya ARL. ARL adalah lamanya hari yang 
dibutuhkan auditor untuk menyelesaikan pekerjaan auditnya, yang diukur dari tanggal penutupan tahun buku hingga tanggal diterbitkannya laporan keuangan audit (Lawrence dan Briyan, 1998). Lamanya waktu pekerjaan audit mempengaruhi kualitas audit yang dihasilkan. Audit yang lambat tidak baik untuk perusahaan begitu juga dengan audit yang terlalu cepat karena mempengaruhi kualitas informasi didalamnya. Sehingga ada batas waktu ideal dalam penyelesaian audit tergantung besar kecilnya perusahaan dan pemahaman auditor terhadap jenis usaha perusahaan.

Penelitian ini merupakan pengembangan dari penelitian Fujianti (2016) yang menguji pengaruh GCG terhadap ARL dengan ketaatan hukum sebagai variabel moderasi. Variabel moderasi yang digunakan yaitu ketepatan waktu penyampaian laporan keuangan dengan menghitung jumlah dewan komisaris dalam perusahaan saja. Variabel komite audit diukur dengan menghitung jumlah komite audit dalam perusahaan karena semua anggota komite audit sifatnya independen tidak memiliki hubungan istimewa dengan perusahaan yang bersangkutan.

\section{Rumusan Masalah}

Berdasarkan latar belakang penelitian, masalah dalam penelitian ini dapat dirumuskan dalam bentuk pertanyaan sebagai berikut:

1. Apakah dewan komisaris berpengaruh terhadap ARL?

2. Apakah komisaris independen berpengaruh terhadap ARL?

3. Apakah komite audit berpengaruh terhadap ARL?

4. Apakah KAP berpengaruh terhadap ARL?

5. Apakah ketepatan waktu penyampaian laporan keuangan memoderasi hubungan dewan komisaris, komisaris independen, komite audit dan KAP dengan ARL?

\section{Tujuan penelitian dan manfaat penelitian}

Berdasarkan rumusan masalah diatas, maka tujuan yang hendak dicapai dalam penelitian ini adalah:

1. Untuk menguji dan memberikan bukti empiris mengenai pengaruh dewan komisaris terhadap ARL.

2. Untuk menguji dan memberikan bukti empiris mengenai pengaruh komisaris independen terhadap ARL.

3. Untuk menguji dan memberikan bukti empiris mengenai pengaruh komite audit terhadap ARL

4. Untuk menguji dan memberikan bukti empiris mengenai pengaruh KAP terhadap ARL. 
Bq. Anggun HL, Bambang, \& Yana Yuliana: Pengaruh Good Corporate Governance...

5. Untuk menguji dan memberikan bukti empiris mengenai pengaruh moderasi ketepatan waktu penyampaian laporan keuangan dalam hubungan dewan komisaris, komisaris independen, komite audit, dan KAP dengan ARL.

Hasil dari penelitian ini diharapkan dapat memberikan manfaat sebagai acuan bagi penelitian selanjutnya yang ingin menganalisis pengaruh GCG terhadap ARL dengan ketepatan waktu penyampaian laporan keuangan sebagai variabel moderasi dan bagi investor diharapkan pula dapat memberikan informasi mengenai faktor-faktor yang mempengaruhi audit report lag sehingga dapat dijadikan sebagai bahan pertimbangan tersendiri dalam berinvestasi, sedangkan bagi Profesi Akuntan Publik dan KAP dapat menjadi bahan referensi yang dapat digunakan dan menjalankan praktik jasa audit khususnya dalam usaha meningkatkan efisiensi dan efektivitas pelaksanaan audit melalui pengelolaan faktor-faktor yang mempengaruhi audit report lag sehingga penyelesaian audit dapat dipercepat sehingga mempercepat publikasi laporan keuangan juga.

\section{TINJAUAN PUSTAKA}

\section{Landasan Teori}

\section{Teori Agensi (Agency Theory)}

Menurut Jensen dan Meckling (1976) teori agensi (agency theory) merupakan hubungan keagenan sebagai suatu kontrak di mana ada satu atau lebih orang (yaitu principal atau pemegang saham atau pemilik) melibatkan atau menunjuk orang lain (yaitu agen atau manajemen) untuk bertindak atas nama pemilik. Antara pemilik dan pengelola terdapat perbedaan kepentingan. Ada beberapa pengelola yang menyalahgunakan kewenangan yang telah diberikan oleh pemilik. Namun tidak semua pengelola atau manajemen berbuat negatif. Beberapa pengelola atau manajemen yang menyalahgunakan wewenang yang telah diberikan oleh pemilik inilah yang akan memicu timbulnya masalah keagenan. Masalah keagenan potensial terjadi apabila bagian kepemilikan manajer atas saham perusahaan kurang dari seratus persen. Proporsi kepemilikan tersebut membuat agen cenderung bertindak untuk kepentingan pribadi dan bukan untuk memaksimalkan nilai perusahaan. Inilah yang nantinya akan menyebabkan biaya keagenan (agency cost).

Bahasan audit report lag berkaitan erat dengan agency theory dimana perusahaan dapat meminta auditor untuk memeriksa lebih lanjut mengenai hutang jangka panjang dan laba rugi perusahaan yang berperan penting dalam laporan keuangan (Wijaya, 2012). Selain itu a gency theory merupakan 
teori yang relevan dalam penelitian ini karena menjelaskan fungsi dewan komisaris dan komite audit dalam struktur GCG sebagai pemonitor dari mekanisme untuk mengurangi masalah keagenan (Fujianti. 2016). Fungsi monitoring ini berkaitan dengan praktek GCG dan pelaporan keuangan sebagai proses pertanggungjawaban kinerja agen (Shukeri dan Nelson 2011).

\section{Landasan Konsep}

\section{Good Corporate Governanace}

OECD (Organization for Economic Co-operation and Development, 2004) dan FCGI (2001) mendefinikan corporate governance sebagai seperangkat peraturan yang mengatur hubungan antara pemegang saham, pengurus (pengelola) perusahaan, pihak kreditur, pemerintah, karyawan serta para pemegang kepentingan intern dan ekstern lainnya yang berkaitan dengan hak-hak dan kewajiban mereka atau dengan kata lain suatu sistem yang mengatur dan mengendalikan perusahaan.

Berdasarkan KNKG (2006) dalam rangka penerapan GCG, masing-masing perusahaan harus menyusun pedoman GCG perusahaan dengan mengacu pada pedoman GCG yang mencakup sekurang-kurangnya hal-hal sebagai berikut:

1. Visi, misi dan nilai-nilai perusahaan;

2. Kedudukan dan fungsi RUPS, dewan komisaris, direksi, komite penunjang dewan komisaris, dan pengawasan internal;

3. Kebijakan untuk memastikan terlaksananya fungsi setiap organ perusahaan secara efektif;

4. Kebijakan untuk memastikan terlaksananya akuntabilitas, pengendalian internal yang efektif dan pelaporan keuangan yang benar;

5. Pedoman perilaku yang didasarkan pada nilai-nilai perusahaan dan etika bisnis;

6. Sarana pengungkapan informasi untuk pemegang saham dan pemangku kepentingan lainnya;

7. Kebijakan penyempurnaan berbagai peraturan perusahaan dalam rangka memenuhi prinsip GCG.

Pelaksanaan GCG harus senantiasa berlandaskan pada 5 (lima) prinsip dasar sebagai berikut:

1) transparansi (transparency) yaitu keterbukaan dalam mengemukakan informasi yang material dan relevan serta keterbukaan dalam melaksanakan proses pengambilan keputusan;

2) akuntabilitas (accountability) yaitu kejelasan fungsi dan pelaksanaan pertanggungjawaban organ perusahaan sehingga pengelolaannya berjalan secara efektif; 
Bq. Anggun HL, Bambang, E Yana Yuliana: Pengaruh Good Corporate Governance...

3) pertanggungjawaban (responsibility) yaitu kesesuaian pengelolaan perusahaan dengan peraturan perundang-undangan yang berlaku dan prinsip pengelolaan perusahaan;

4) independensi (independency) yaitu pengelolaan perusahaan secara profesional tanpa pengaruh/tekanan dari pihak manapun; dan

5) kewajaran (fairness) yaitu keadilan dan kesetaraan dalam memenuhi hak-hak stakeholders yang timbul berdasarkan perjanjian dan peraturan perundang-undangan yang berlaku.

Dalam rangka memastikan penerapan 5 (lima) prinsip dasar GCG sebagaimana dimaksud diatas, perusahaan harus melakukan penilaian sendiri (self assessment) secara berkala yang paling kurang meliputi 11 (sebelas) Faktor Penilaian Pelaksanaan GCG yaitu:

1) pelaksanaan tugas dan tanggung jawab dewan komisaris;

2) pelaksanaan tugas dan tanggung jawab direksi;

3) kelengkapan dan pelaksanaan tugas komite;

4) penanganan benturan kepentingan;

5) penerapan fungsi kepatuhan;

6) penerapan fungsi audit intern;

7) penerapan fungsi audit ekstern;

8) penerapan manajemen risiko termasuk sistem pengendalian intern;

9) penyediaan dana kepada pihak terkait (related party) dan penyediaan dana besar (large exposures);

10) transparansi kondisi keuangan dan non keuangan, laporan pelaksanaan GCG dan pelaporan internal; dan

11) rencana strategis perusahaan.

Penilaian terhadap pelaksanaan GCG yang berlandaskan pada 5 (lima) prinsip dasar tersebut dikelompokkan dalam suatu governance system yang terdiri dari 3 (tiga) aspek governance, yaitu governance structure, governance process, dan governance outcome.

\section{Audit Report Lag}

Menurut Sukrisno Agoes (2012:4) auditing adalah suatu pemeriksaan yang dilakukan secara kritis dan sistematis, oleh pihak yang independen, terhadap laporan keuangan yang telah disususn oleh manajemen, beserta catatan-catatan pembukuan dan bukti-bukti pendukungnya, dengan tujuan untuk dapat memberikan pendapat mengenai kewajaran laporan keuangan tersebut. Sedangkan auditing menurut Mulyadi (2002:9) adalah suatu proses sistematik untuk memperoleh dan mengevaluasi bukti secara objektif mengenai pernyataan-pernyataan tentang kegiatan dan kejadian ekonomi, dengan tujuan untuk menetapkan tingkat kesesuaian antara pernyataan- 
pernyataan tersebut dengan kriteria yang telah ditetapkan, serta penyampaian hasil-hasilnya kepada pemakai yang berkepentingan. Dari pengertian diatas dapat disimpulkan bahwa audit dilaksanakan oleh orang yang kompeten dan independen dengan cara mengumpulkan bukti-bukti yang ada serta mengevaluasi bahan bukti tersebut, yang bertujuan agar dapat memberikan suatu pendapat mengenai kewajaran laporan keuangan.

\section{Ketepatan Waktu Penyampaian Laporan Keuangan}

Salah satu faktor penting untuk menyajikan informasi pada laporan keuangan yang relevan adalah ketepatwaktuan. Laporan keuangan sebagai sebuah informasi yang disediakan tepat waktu bagi pembuat keputusan sebelum informasi tersebut kehilangan kemampuannya dalam mempengaruhi pengambilan keputusan, terutama investor dan kreditor. Jika terdapat keterlambatan dalam pelaporan, maka informasi yang dihasilkan akan kehilangan kemampuan pengaruh terhadap keputusan. Ketepatwaktuan dapat diukur sebagai rentang waktu antara tanggal laporan keuangan perusahaan dan tanggal ketika informasi keuangan disampaikan kepada Bapepam LK dan Bursa Efek dan diumumkan ke publik. Selain itu, pengukuran ketepatwaktuan juga dapat mengacu pada ketentuan yang berlaku.

\subsection{Kerangka Konseptual Penelitian}

Berdasarkan landasan teori yang telah diuraikan sebelumnya, maka rerangka konseptual yang menghubungkan antar variabel dalam penelitian ini adalah sebagai berikut :

\section{Gambar 2.1}

\section{Kerangka Konseptual}
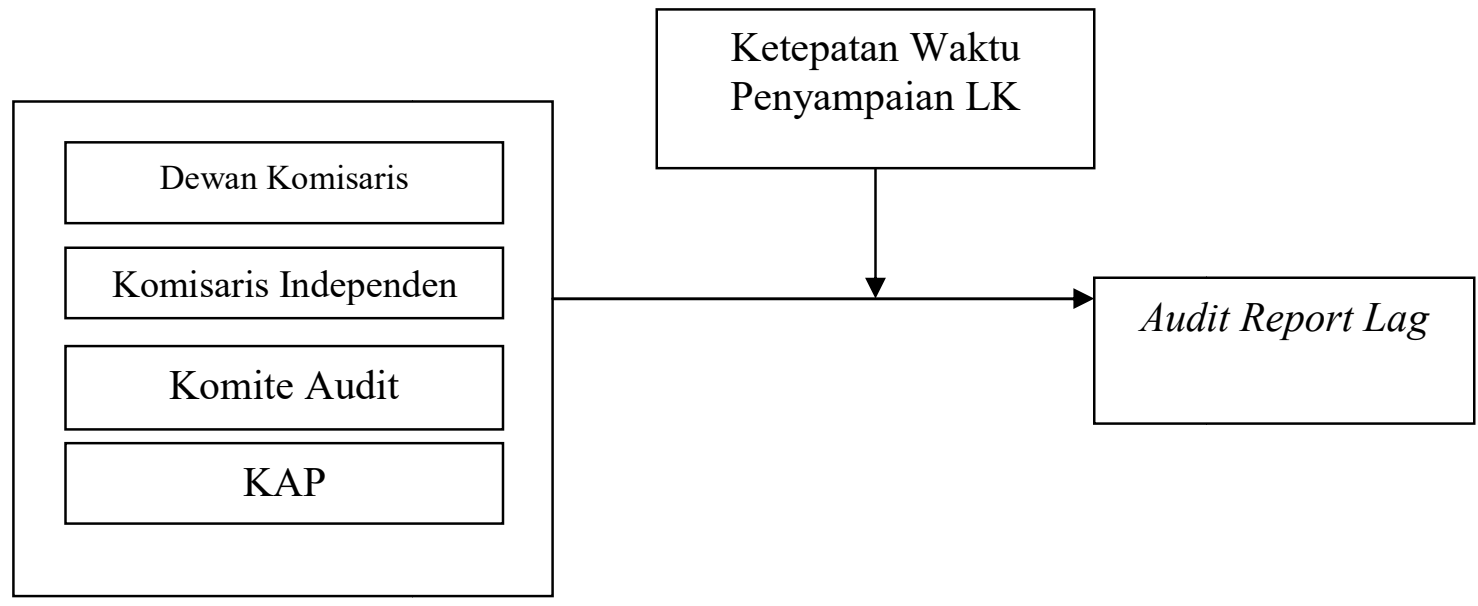
Bq. Anggun HL, Bambang, E Yana Yuliana: Pengaruh Good Corporate Governance...

Pengembangan Hipotesis

Pengaruh Dewan Komisaris Terhadap Audit Report Lag

Teori dari hipotesis ini bertumpu pada teori agensi, dimana pihak pemilik (principal) termotivasi terhadap transparansi, tidak adanya kelalaian, dan ketepatan waktu yang dilakukan oleh manajer (agent). Pengaturan jumlah dewan komisaris diharapkan dalam pelaksanaan pengawasan dan penasihatan bisa berjalan lebih baik dan efisien. Namun menyangkut koordinasi dan komunikasi, terdapat kelemahan yang terkait dengan ukuran dewan yang memiliki jumlah anggota yang banyak. Kurangnya koordinasi dan komunikasi membuat kurang efisien serta sulit dalam memonitor, dibandingkan dengan ukuran dewan yang memiliki jumlah anggota lebih sedikit. Wardhani, (2013) berpendapat bahwa ukuran dewan yang memiliki anggota besar menyebabkan kurang terciptanya partisipasi, kurang terorganisir serta sulit dalam mencapai suatu kesepakatan. Ukuran dewan yang memiliki jumlah anggota yang lebih sedikit atau kecil, dianggap akan lebih mudah dalam birokrasi, lebih fungsional sehinggga lebih mampu dalam memberikan pengawasan saat proses pelaporan keuangan (Fujianti, 2016). Berdasarkan uraian diatas dapat dirumuskan hipotesis berikut:

$\mathrm{H1}$ : Dewan komisaris berpengaruh positif terhadap audit report lag

\section{Pengaruh Komisaris Independen Terhadap Audit Report Lag}

Komisaris independen terbukti penting dan telah diakui bahkan diatur dalam peraturan pasar modal mengenai keharusan perusahaan memiliki komisaris independen (Fujianti, 2016). Komisaris independen merupakan salah satu unsur penting dalam mekanisme GCG serta kehadirannya dalam dewan komisaris merupakan rekomendasi dari praktisi GCG (Zattoni \& Cuomo, 2010). Regulasi dari berbagai negara mengharuskan komisaris independen mengemban tugas dan tanggung jawab untuk melakukan pengawasan yang efektif atas prilaku direksi (Naimi et al, 2010). Dengan demikian, proporsi komisaris independen yang cukup akan mengurangi jumlah orang yang tidak memiliki kepentingan apapun didalam perusahaan dan mengurangi adanya intervensi terhadap pengerjaan laporan. Berdasarkan uraian diatas, dapat dirumuskan hipotesis berikut:

$\mathrm{H} 2$ : komisaris independen berpengaruh negatif terhadap audit report lag

\section{Pengaruh Komite Audit Terhadap Audit Report Lag}

Dalam agensi teori dijelaskan bahwa terdapat perbedaan kepentingan antara principal dan agent (Jensen dan Meckling, 1976). Pendelegasian principal kepada agent membuat principal tidak dapat 
mengawasi kinerja manajer, sehingga tindakan manajer terkadang tidak sesuai dengan keinginan pemilik. Perbedaan kepentingan tersebut dapat mengarah pada tindakan kecurangan dan penipuan yang dilakukan oleh agent atau manajer dengan principal atau pihak pemilik (Widya, 2013). Oleh karena itu diperlukan anggota komite audit yang independen sebagai pihak yang membantu principal atau pihak pemilik dalam mengawasi aktivitas agent dan mengurangi manfaat dari pemotongan informasi yang dilakukan oleh agent (Hashim dan Rahman, 2011).

Untuk menjaga independensi komite audit maka anggota komite audit tidak boleh memiliki hubungan istimewa terhadap pihak manajemen perusahaan, seperti misalnya hubungan keluarga. Independensi komite audit dapat berkontribusi terhadap kualitas pelaporan keuangan sehingga menurunkanaudit report lag dalam perusahaan (Wijaya, 2012). Hal ini didukung oleh penelitian Kumara (2015), Wardhani (2013), dan Fujianti (2016) menyatakan bahwa komite audit berpengaruh negatif terhadap audit report lag. Namun berbeda dengan penelitian Widya (2013) yang mengatakan bahwa komite audit tidak berpengaruh terhadap ARL. Berdasarkan uraian tersebut maka dapat dirumuskan hipotesis berikut:

H3: Komite audit berpengaruh negatif terhadap audit report lag.

\section{Pengaruh KAP Terhadap Audit Report Lag}

Laporan keuangan yang disajikan ke publik harus melalui proses audit oleh auditor ekternal (akuntan publik) untuk memperoleh integritas dan legitimasi atas akurasi laporan keuangan tersebut. Proses audit memerlukan waktu sehingga dapat berpengaruh terhadap audit report lag. Afify (2009) menyatakan bahwa perusahaan audit yang besar memiliki motivasi yang kuat untuk menyelesaikan pekerjaan audit dengan tepat waktu, guna menjaga reputasi dan nama mereka. Reputasi Kantor Akuntan Publik (KAP) ini merupakan sinyal bahwa KAP tersebut melakukan proses audit dengan baik sehingga dapat menjaga kepercayaan masyarakat. KAP besar diprediksi dapat menyelesaikan proses audit lebih cepat dibandingkan KAP kecil, karena mereka memiliki lebih banyak staf audit yang lebih berkualitas. Keahlian auditor berdampak pada efisiensi dan efektivitas proses audit (Wardhani, 2013). Hal ini didukung oleh penelitian Didipu (2016) yang menyatakan ukuran KAP berpengaruh negatif terhadap ARL. Namun berbeda dengan penelitian Sumartini dan Widhiyani (2014) yang mengatakan bahwa KAP tidak berpengaruh terhadap ARL. Berdasarkan uraian diatas maka hipotesis (H4) adalah sebagai berikut :

H4 : KAP berpengaruh negatif terhadap audit report lag. 
Bq. Anggun HL, Bambang, \& Yana Yuliana: Pengaruh Good Corporate Governance...

\section{Pengaruh Moderasi Ketepatan Waktu Penyampaian Laporan Keuangan Dalam Hubungan Dewan Komisaris, Komisaris Independen, Komite Audit dan Kantor Akuntan Publik Dengan Audit Report Lag}

Ketepatan waktu penyampaian laporan keuangan mendapat perhatian dari regulator. Perhatian ini terutama ditujukan pada batas waktu penyampaian laporan keuangan. Batas waktu penyampaian laporan keuangan ini menjadi tekanan bagi perusahaan untuk mengurangi audit report lag, karena perusahaan yang tidak mematuhi peraturan tersebut akan dikenakan sanksi.

Dengan adanya tuntutan ketepatan waktu penyampaian laporan keuangan maka diharapkan dapat memperpendek ARL. Karena dengan adanya batas waktu, auditor tertuntut untuk menyelesaikan pekerjaannya tepat waktu. Selain itu ketepatan waktu penyampaian laporan keuangan juga diharapkan memperkuat hubungan dewan komisaris, komisaris independepn, komite audit dan KAP dengan ARL. Berdasarkan penelitian terdahulu keberadaan pihak-pihak tersebut dalam perusahaan mempengaruhi ARL. Pengaruh tersebut diharapkan semakin kuat dengan adanya tuntutan ketepatan waktu penyampaian laporan keuangan. Hal tersebut didukung oleh penelitian Fujianti (2016). agar mentaati peraturan tersebut. Berdasarkan uraian diatas maka hipotesis (H5) adalah sebagai berikut :

H5: Ketepatan waktu penyampaian laporan keuangan memoderasi hubungan dewan komisaris, komisaris independen, komite audit dan KAP terhadap audit report lag.

\section{METODE PENELITIAN}

Jenis penelitian yang digunakan dalam penelitian ini adalah penelitian asosiatif. Lokasi penelitian ini adalah di Bursa Efek Indonesia yang menyediakan informasi laporan keuangan perusahaan dengan mengakses situs resmi Bursa Efek Indonesia yaitu www.idx.co.id.

Populasi dalam penelitian ini adalah perusahaan publik yang terdaftar di Bursa Efek Indonesia yang masuk dalam indeks saham Kompas 100 periode tahun 2015. Pengambilan sampel pada penelitian ini menggunakan metode purposive sampling dengan kriteria pengambilan sampel dalam penelitian ini adalah sebagai berikut:

a. Perusahaan yang terdaftar di Bursa Efek Indonesia dan termasuk dalam indeks saham Kompas 100 periode tahun 2015.

b. Perusahaan yang menyajikan semua data yang diperlukan terkait variabel-variabel dalam penelitian ini. 
Table 3.1

Sampel Perusahaan

\begin{tabular}{|l|c|}
\hline \multicolumn{1}{|c|}{ Keterangan } & $\begin{array}{c}\text { Jumlah } \\
\text { perusahaan }\end{array}$ \\
\hline $\begin{array}{l}\text { Perusahaan publik yang terdaftar dalam } \\
\text { indeks saham Kompas 100 tahun 2015 }\end{array}$ & 100 \\
\hline $\begin{array}{l}\text { Perusahaan yang keluar dari daftar saham } \\
\text { Kompas 100 tahun 2015 }\end{array}$ & $(9)$ \\
\hline $\begin{array}{l}\text { Perusahaan yang tidak menyajikan semua } \\
\text { data yang diperlukan untuk variabel- } \\
\text { variabel penelitian }\end{array}$ & $(7)$ \\
\hline $\begin{array}{l}\text { Jumlah perusahaan yang menjadi } \\
\text { sampel }\end{array}$ & $\mathbf{8 4}$ \\
\hline
\end{tabular}

Sumber: www.idx.com (data sekunder diolah), 2017

Variabel-variabel yang digunakan adalah sebagai berikut :

a. Audit report lag adalah lamanya waktu penyelesaian audit yang diukur dari tanggal penutupan tahun buku atau akhir tahun fiskal hingga tanggal laporan keuangan auditan (Lawrence dan Briyan, 1998). Variabel ini diukur berdasarkan jumlah hari antara akhir tahun fiskal dan tanggal laporan audit perusahaan. Data untuk variabel ini diperoleh dari laporan tahunan/laporan keuangan auditan. Variabel ini dilambangkan dengan ARL.

b. Dewan komisaris merupakan organ perseroan yang bertugas melakukan pengawasan secara umum dan/atau khusus sesuai dengan anggaran dasar serta memberi nasihat kepada direksi (POJK Nomor 33/POJK.04/2014). Variabel ini diukur dengan menghitung jumlah anggota dewan yang ada dalam suatu perusahaan. Data untuk variabel ini diperoleh dari laporan tahunan perusahaan. Variabel ini dilambangkan dengan DK.

c. Komisaris independen adalah anggota dewan komisaris yang berasal dari luar emiten atau perusahaan publik dan memenuhi persyaratan sebagai komisaris independen (POJK Nomor 33/POJK.04/2014). Variabel ini diukur dengan melihat proporsi jumlah dewan komisaris independen dibandingkan dengan jumlah anggota dewan komisaris dalam perusahaan. Data untuk variabel ini diperoleh dari laporan tahunan perusahaan. Variabel ini dilambangkan dengan variabel KI.

d. Komite audit adalah komite yang dibentuk oleh dan bertanggung jawab kepada dewan komisaris dalam membantu melaksanakan tugas dan fungsi dewan komisaris (POJK Nomor 55 /Pojk.04/2015). Variabel 
Bq. Anggun HL, Bambang, E Yana Yuliana: Pengaruh Good Corporate Governance...

ini diukur dengan menghitung jumlah komite audit yang ada dalam suatu perusahaan. Variabel ini dilambangkan dengan variabel KA.

e. KAP adalah badan usaha yang didirikan berdasarkan ketentuan peraturan perundang-undangan dan mendapatkan izin usaha berdasarkan Undang-Undang ini (UU No. 5 Tahun 2011). Variabel ini diukur dengan menggunakan variabel dummy yaitu: Score 0 apabila KAP kecil dan Score 1 apabila KAP besar .Kriteria besar kecinya KAP berdasarkan reputasi perusahaan audit. Berdasarkan kajian teori dan beberapa penelitian terdahulu maka KAP termasuk dalam kriteria besar apabila termasuk dalam KAP big four dan termasuk dalam kriteria kecil apabila termasuk dalam KAP big non four. Data untuk variabel ini diperoleh dari laporan tahunan perusahaan. Variabel ini dilambangkan dengan variabel KAP.

f. Ketepatan waktu penyampaian laporan keuangan bagi perusahaan yang terdaftar di Bursa Efek Indonesia (BEI) menurut Keputusan Ketua Badan Pengawas Pasar Modal dan Lembaga Keuangan (Bapepam dan LK) Nomor : Kep-346/BL/2011, Tanggal : 5 Juli 2011 adalah tiga bulan setelah tanggal laporan keuangan. Variabel ini diukur dengan menggunakan variabel dummy yaitu: Score 0 apabila tidak tepat waktu dan Score 1 apabila tepat waktu. Perusahaan dikatakan tepat waktu apabila menyampaikan laporan keuangannya sebelum tanggal 31 Maret setelah tahun buku. Apabila melewati tanggal tersebut perusahaan dikatakan tidak tepat waktu. Data untuk variabel ini diperoleh dari laporan tahunan perusahaan. Variabel ini dilambangkan dengan variabel KW.

Model regresi berganda dirumuskan dengan persamaan berikut:

$$
\mathrm{ARL}=\alpha+\beta_{1} \mathrm{DK}+\beta_{2} \mathrm{KI}+\beta_{3} \mathrm{KA}+\beta_{4} \mathrm{KAP}+\beta_{5} \mathrm{KW}+\mathrm{e}
$$

Regresi moderat uji interaksi:

$$
\begin{gathered}
\mathrm{ARL}=\alpha+\beta{ }_{1} \mathrm{DK}+\beta{ }_{2} \mathrm{KI}+\beta{ }_{3} \mathrm{KA}+\beta{ }_{4} \mathrm{KAP}+\beta{ }_{5} \mathrm{KW}+\beta{ }_{6} \mathrm{KW} * \mathrm{DK}+ \\
\beta{ }_{7} \mathrm{KW} * \mathrm{KI}+\beta{ }_{8} \mathrm{KW} \text { K } \mathrm{KAI}+\beta{ }_{9} \mathrm{KW} * \mathrm{KAP}+\mathrm{e}
\end{gathered}
$$

Dimana:

$$
\begin{array}{ll}
\alpha & =\text { konstanta } \\
\beta & =\text { koefisien regresi } \\
\text { DK } & =\text { jumlah dewan komisaris } \\
\text { KI } & =\text { rasio komisari independen } \\
\text { KA } & =\text { jumlah komite audit } \\
\text { KAP } & =\text { kriteria kantor akuntan publik } \\
\text { KW } & =\text { kriteria ketepatan waktu penyajian laporan keuangan } \\
\text { e } & =\text { error }
\end{array}
$$




\section{PEMBAHASAN}

\section{Pengaruh Dewan Komisaris Terhadap Audit Report Lag}

Hasil uji regresi menunjukkan bahwa dewan komisaris berpengaruh negatif terhadap audit report lag atau hipotesis $\mathrm{H} 1$ ditolak yang ditunjukkan dengan nilai t hitung sebesar $-2,670$ dan nilai signifikan sebesar 0,009 < 0,05 . Artinya semakin banyak anggota dewan komisaris akan mengurangi jangka waktu audit report lag. Jumlah rata-rata dewan komisaris dalam sampel adalah 6 orang. Menurut Kumara (2015) ukuran dewan yang memiliki jumlah anggota yang lebih banyak dinilai akan lebih fokus pada masingmasing departemen sehingga penyelesaian aktivitas masing-masing departemen dapat diselesaikan dengan lebih cepat. Dengan adanya pembagian kerja yang baik maka tugas dewan komisaris dalam mengawasi dan memberikan nasehat kepada direksi atau manajemen perusahaan dapat berjalan dengan lancar. Pengawasan dan nasihat dari dewan komisaris mempengaruhi manajemen dalam menyusun laporan keuangan perusahaan, karena merasa diawasi maka manajemen tertuntut untuk taat terhadap aturan. Ini berarti keberadaan dewan komisaris dalam mekanisme GCG mampu memotivasi dewan komisaris untuk melakukan tekanan kepada manajemen agar menyajikan laporan keuangan tepat waktu atau mengurangi audit report lag.

Selain itu keberadaan dewan komisaris mampu mengurangi asimetri informasi akibat adanya perbedaan kepentingan antara pemilik dan manajemen. Hasil penelitian ini sejalan dengan penelitian Kumara (2015) yang mengatakan bahwa dewan komisaris berpengaruh negatif terhadap audit report lag. Hal ini berbeda dengan penelitian Fujianti (2016) dan Wardhani (2013) yang mengatakan semakin banyak anggota dewan komisaris akan memperpanjang jangka waktu audit report lag dikarenakan masalah koordinasi dan komunikasi yang ada dalan ukuran dewan yang memiliki anggota lebih banyak akan memperlambat pengambilan keputusan termasuk dalam kaitannya dengan penyajian laporan keuangan, sehingga ukuran dewan komisaris meningkatkan audit report lag.

\section{Pengaruh Komisaris Independen Terhadap Audit Report Lag}

Berdasarkan hasil uji regresi nilai probabilitas signifikansi komisaris independen sebesar 0,140 lebih besar dari 0,05. Hal tersebut menunjukkan bahwa komisaris independen tidak berpengaruh terhadap audit report lag atau hipotesis $\mathrm{H} 2$ ditolak. Hal ini dapat dijelaskan bahwa jumlah rata-rata komisaris independen dalam sampel adalah $43,15 \%$ jumlah ini belum ideal sebagaimana di industri lain yaitu perbankan dimana jumlah komisaris 
Bq. Anggun HL, Bambang, E Yana Yuliana: Pengaruh Good Corporate Governance...

independen adalah 50\%. Dari 84 sampel perusahaan yang diteliti terdapat $51,2 \%$ perusahaan yang menyampaikan laporan keuangannya tepat waktu artinya kontribusi komisaris independen dalam melaksanakan tugasnya telah cukup baik. Namun demikian 48,8\% perusahaan masih mengalami keterlambatan dalam pelaporan. Sebagaimana yang disampaikan pada landasan teori bahwa tugas utama komisaris independen adalah mengawasi dan memastikan bahwa laporan keuangan yang dibuat oleh manajemen sesuai dengan standar akuntansi yang berlaku umum dan taat terhadap aturan. Selain itu komisaris independen tidak hanya melakukan pengawasan melainkan juga memberikan nasihat kepada direksi. Namun tidak ada regulasi yang mengharuskan direksi untuk mendengar saran atau nasihat komisaris independen.

Hasil penelitian ini sejalan dengan penelitian Moghaddam (2014) dan Raharja (2013) yang mengatakan komisaris independen tidak berpengaruh terhadap audit report lag. Namun berbeda dengan penelitian Wardhani (2013), Kumara (2015) dan Fujianti (2016) yang mengatakan komisaris independen berpengaruh negatif terhadap audit report lag yang artinya semakin banyak anggota komisaris independen akan mengurangi jangka waktu audit report lag. Hal tersebut diperkuat olehFama dan Jensen (1983) yang menyatakan bahwa komisaris dapat memainkan peran penting dalam penyelesaian masalah keagenan dan kehadiran komisaris independen dalam struktur GCG dapat menyebabkan lebih banyak pengambilan keputusan yang efektif termasuk dalam kaitannya dengan audit report lag.

\section{Pengaruh Komite Audit Terhadap Audit Report Lag}

Hasil uji regresi menunjukkan bahwa komite audit tidak berpengaruh terhadap audit report lag atau hipotesis $\mathrm{H} 3$ ditolak yang dibuktikan dengan nilai probabilitas signifikansi sebesar 0,281 >0,05. Hal ini dapat dijelaskan bahwa jumlah rata-rata komite audit dalam sampel adalah 3 orang dan diantaranya terdapat komisaris independen sebagai ketua komite audit. Dalam penelitian ini komite audit tidak berpengaruh terhadap audit report lag, hal ini konsisten dengan komisaris independen yang tidak berpengaruh terhadap audit report lag, karena komite audit dibentuk oleh dewan komisaris dan bertanggung jawab dalam membantu melaksanakan tugas dan fungsi dewan komisaris. Adapun tugas komite audit adalah melakukan penelaahan atas informasi keuangan dan ketaatan terhadap peraturan perundang undangan.

Dalam hal untuk mempercepat pelaporan bukan merupakan tugas utama komite audit karena terdapat risiko terhadap kualitas laporan keuangan. Bila dipaksakan untuk mempercepat pelaporan kemungkinan 
laporan keuangan yang disusun tidak informatif dan berdampak buruk bagi perusahaan. Hasil penelitian ini sejalan dengan penelitian Fujianti (2016) dan Widya (2013) yang mengatakan bahwa komite audit tidak berpengaruh terhadap audit report lag. Namun hal ini berbeda dengan penelitian Wardhani (2013) dan Wijaya (2012) yang mengatakan bahwa komite audit berpengaruh terhadap audit report lag.

\section{Pengaruh Kantor Akuntan Publik Terhadap Audit Report Lag}

Berdasarkan hasil uji regresi nilai probabilitas signifikansi kantor akuntan publik sebesar 0,742 jauh diatas 0,05 yang berarti bahwa kantor akuntan publik tidak berpengaruh terhadap audit report lag atau hipotesis H4 ditolak. Ini berarti besar kecilnya KAP (big four atau non big four) tidak mempengaruhi audit report lag. KAP big four di Indonesia belum menunjukkan periode waktu audit yang pendek dibandingkan yang non big four, ini berarti regulasi mengenai akuntan publik di Indonesia sudah baik, yang terlihat dari dikeluarkannya peraturan undang-undang nomor 5 tahun 2011 tentang akuntan publik serta adanya quality assurance.

Berdasarkan sampel penelitian terdapat banyak terdapat perusahaan yang diaudit oleh KAP big four namun mengalami keterlambatan dalam pelaporan, sebaliknya banyak terdapat perusahaan yang diaudit oleh KAP non big four namun justru tepat waktu dalam pelaporan. Hasil penelitian ini sejalan dengan penelitian Sumartini dan Widhiyani (2014) dan Fujianti (2016) yang mengatakan bahwa ukuran kantor akuntan publik tidak berpengaruh terhadap audit report lag. Hasil penelitian ini berbeda dengan penelitian Didipu (2016) yang mengatakan bahwa ukuran kantor akuntan publik berpengaruh negatif terhadap audit report lag yang berarti bahwa KAP big four mampu menyelesaikan pekerjaan auditnya tepat waktu dibandingkan dengan yang non big four.

\section{Pengaruh Moderasi Ketepatan Waktu Penyampaian Laporan Keuangan Dalam Hubungan Dewan Komisaris, Komisaris Independen, Komite Audit dan Kantor Akuntan Publik Dengan Audit Report Lag}

Hasil uji interaksi moderasi menunjukkan bahwa interaksi dari variabel ketepatan waktu penyampaian laporan keuangan dengan variabel dewan komisaris, komisaris independen, komite audit dan kantor akuntan publik tidak berpengaruh terhadap audit report lag atau hipotesis $\mathrm{H} 5$ ditolak. Hal ini terlihat dari nilai probabilitas signifikansi interaksi antara ketepatan waktu penyajian laporan keuangan dengan dewan komisaris, komisaris independen, komite audit dan kantor akuntan publik secara berturut-turut adalah 0.666 , 
Bq. Anggun HL, Bambang, \& Yana Yuliana: Pengaruh Good Corporate Governance...

$0.638,0.258$ dan 0.941 semuanya jauh diatas 0.05 atau $5 \%$. Hal ini menunjukkan bahwa variabel ketepatan waktu penyajian laporan keuangan tidak bisa menjadi moderator antara variabel dewan komisaris, komisaris independen, komite audit dan kantor akuntan publik dengan audit report lag.sebelumnya telah dibahas bahwa komisaris independen tidak berpengaruh terhadap audit report lag, hal ini terkait dengan tugas utama pihak tersebut. Dimana komisaris independen bertugas mengawasi dan memastikan bahwa laporan keuangan yang buat oleh manajemen sesuai dengan standar akuntansi yang berlaku umum dan taat terhadap aturan, sedangkan komite audit bertugas dan bertanggung jawab dalam membantu melaksanakan tugas dan fungsi dewan komisaris.

Dalam hal untuk mempercepat pelaporan bukan merupakan tugas utamanya karena terdapat risiko terhadap kualitas laporan keuangan perusahaan sehingga tuntutan ketepatan waktu penyampaian laporan keuangan tidak mampu memoderator hubungan komisaris independen dan komite audit dengan audit report lag. ukuran KAP tidak berpengaruh terhadap audit report lag, jangka waktu report lag perusahaan yang diaudit oleh KAP big four tidak jauh berbeda dengan KAP non big four. Dari sampel penelitian banyak terdapat perusahaan yang diaudit oleh KAP big four namun mengalami keterlambatan dalam pelaporan, sebaliknya banyak terdapat perusahaan yang diaudit oleh KAP non big four namun justru tepat waktu dalam pelaporan. Hal ini menunjukkan bahwa variabel ketepatan waktu penyampaian laporan keuangan tidak mampu memoderator KAP dengan audit report lag. Namun demikian meskipun tidak terdapat pengaruh yang signifikan, kontribusi pihak-pihak tersebut telah cukup baik dalam mendorong proses pelaporan tepat waktu yang didukung oleh hasil statistik deskriptif yang mencapai $51,2 \%$ perusahaan tepat waktu dalam pelaporan. Hasil penelitian ini berbeda dengan penelitian Fujianti (2016) yang mengatakan bahwa ketepatan waktu penyampaian laporan keuangan memoderasi dewan komisaris dan komite audit dengan audit report lag.

\section{Kesimpulan}

\section{PENUTUP}

Penelitian ini bertujuan untuk menguji pengaruh GCG yang diukur dengan keberadaan struktur GCG yaitu dewan komisaris, komisaris independen, komite audit dan kantor akuntan publik terhadap audit report lag. Berdasarkan hasil penjelasan sebelumnya dapat disimpulkan bahwa:

a. Semakin banyak anggota dewan komisaris akan mengurangi jangka waktu audit report lag. Jumlah rata-rata dewan komisaris dalam sampel adalah 6 orang. 
b. Komisaris independen tidak berpengaruh terhadap audit report lag karena tugas utama komisaris independen adalah mengawasi dan memastikan bahwa laporan keuangan yang dibuat oleh manajemen sesuai dengan standar akuntansi yang berlaku umum dan taat terhadap aturan. Dari 84 sampel perusahaan yang diteliti terdapat 43 perusahaan yang menyampaikan laporan keuangannya tepat waktu, artinya kontribusi komisaris independen dalam melakukan tugasnya telah cukup baik.

c. Komite audit tidak berpengaruh terhadap audit report lag. Hal ini dapat dijelaskan bahwa jumlah rata-rata komite audit dalam sampel adalah 3 orang dan diantaranya terdapat komisaris independen sebagai ketua komite audit. Adapun tugas komite audit adalah melakukan penelaahan atas informasi keuangan dan ketaatan terhadap peraturan perundang undangan. Dalam hal untuk mempercepat pelaporan bukan merupakan tugas utama komite audit karena terdapat risiko terhadap kualitas laporan keuangan.

d. Kantor akuntan publik tidak berpengaruh terhadap audit report lag. Hal ini menunjukkan bahwa KAP big four di Indonesia belum menunjukkan periode waktu audit yang pendek dibandingkan yang non big four, ini berarti regulasi mengenai akuntan publik di Indonesia sudah baik

e.Interaksi dari variabel ketepatan waktu penyampaian laporan keuangan dengan variabel dewan komisaris, komisaris independen, komite audit dan kantor akuntan publik tidak berpengaruh terhadap audit report lag. Hal ini menunjukkan bahwa variabel ketepatan waktu penyampaian laporan keuangan tidak bisa menjadi moderator antara variabel dewan komisaris, komisaris independen, komite audit dan kantor akuntan publik dengan audit report lag.

\section{Saran}

Bagi penelitian selanjutnya sebaiknya menggunakan variabel lain yang diprediksi mempengaruhi audit report lag serta menggunakan variabel moderasi lain yang lebih mampu memoderator serta bagi penelitian yang akan datang sebaiknya menggunakan sampel perusahaan yang lebih banyak dan rentang waktu yang lebih lama agar hasil pengujian lebih akurat karena dalam penelitian ini variabel independen yang digunakan belum mampu memberikan pengaruh yang signifikan terhadap audit report lag

\section{DAFTAR PUSTAKA}


Bq. Anggun HL, Bambang, E Yana Yuliana: Pengaruh Good Corporate Governance...

Afify, H.A.E. 2009. Determinants of audit report lag: Does implementing corporate governance have any impact? Empirical evidence from Egypt. Journal of Applied Accounting Research. Vol. 10. No. 1, pp:56 - 86

Agoes, Sukrisno. 2012. Auditing: Petunjuk Praktis Pemeriksaan Akuntan Oleh Akuntan Publik. Jakarta: Salemba Empat.

Didipu, Fajrin Abd. Rahman. 2016. Pengaruh Ukuran Kantor Akuntan Publik, Ukuran Perusahaan, Dan Kompleksitas Operasi Perusahaan Terhadap Audit Report Lag (Studi Empiris Di Perusahaan Perbankan Yang Terdaftar Di Bei Tahun 2013-2015). Skripsi Universitas Hasanuddin.

Elkington, John. 1997. Cannibals with Forks: The Triple Bottom Line of 21st Century Business. Capstone.

Fujianti, Lailah. 2016. Ketaatan Hukum Mampukah Memoderasi Hubungan Good Corporate Governance Terhadap Audit Report Lag. Simposiun Nasional Akuntansi XIX. Lampung.

Grant, Robert M. 2007. Contemporary Strategy Analisys. Washington D.C. Blackwell Publishers.

Hashim, U.J.B., Rahman, R.B.A. 2011. Audit Report Lag and the Effectiveness of Audit Committee Among Malaysian Listed Companies. International Bulletin of Business Administration. No. 10, pp. 50-61

Jensen, M.C., Meckling, W.H. 1976.Theory of the Firm: Managerial Behavior, Agency Costs and Ownership Structure. Journal of Financial Economics, October, 1976, V. 3, No. 4, pp. 305-360.

Keputusan direksi PT. Bursa Efek Jakarta Nomor 307/BEJ/07-2004

Kumara, Raditya Andika. 2015. Pengaruh Corporate Governance terhadap Audit Report Lag (Studi Kasus Pada Perusahaan Manufaktur Yang Terdaftar Di BEI Tahun 2010-2013). Skripsi Universitas Dipenogoro.

Lawrence, Janice and Barry Bryan. 1998. Characteristics Associated With Audit Delay In The Monitoring Of Low Income Housing Projects. Journal Of Public Budgeting, Accounting \& Financial Management, V. 10, No. 2, pp. 173-191.

Mulyadi. 2002. Auditing (edisi 6). Jakarta: Salemba Empat.

Naimi, Mohamad. Mohamad-Nor, Rohami Shafie and Wan Nordin WanHussin,2010. Corporate Governance And Audit Report Lag In Malaysia. Malaysia: Asian Academy of Management Journal of Accounting And Finance. Vol. 6, No. 2, 57-84

Organisation for Economic Co-operation and Development, 2004. OECD Principles of Corporate Governance.

Peraturan Otoritas Jasa Keuangan Nomor 33 Tahun 2014 tentang Direksi dan Dewan Komisaris Emiten Atau Perusahaan Publik. 
Peraturan Otoritas Jasa Keuangan Nomor 55 Tahun 2015 tentang Pembentukan dan Pedoman Pelaksanaan Kerja Komite Audit.

Otoritas Jasa Keuangan.Roadmap Tata Kelola Perusahaan Indonesia Menuju Tata Kelola Emiten dan Perusahaan Lebih Baik, Jakarta : OJK, 2014.

Shukeri, S.W., Nelson, S.P. 2011. Corporate Governance and Audit Report Timeliness: Evidence from Malaysia, Research in Accounting in Emerging Economies, No. 11: 109 - 127.

Standar Akuntansi Keuangan : Per Efektif 1 Januari 2015, 2015. Ikatan Akuntan Indonesia, Salemba empat

Sulistyo, Wahyu Adhy N. 2010. Analisis Faktor-faktor yang Berpengaruh terhadap Ketepatan Waktu Penyampaian Laporan Keuangan pada Perusahaan yang Listing di Bursa Efek Indonesia Periode 20062008. Skripsi Universitas Diponegoro.

Sumartini dan Widhiyani. 2014. Pengaruh Opini Audit, Solvabilitas, Ukuran KAP

dan Laba Rugi Pada Audit Report Lag. Jurnal Akuntansi Universitas Udayana. Vol 9 No. 1.

Bank Indonesia.2013. Surat Edaran Bank Indonesia No. 15/15/DPNP Prihal Pelaksanaan Good Corporate Governance Bagi Bank Umum.

Undang-undang Nomor 5 Tahun 2011 tentang Akuntan Publik

Wardhani, Armania Putri. 2013. Pengaruh Corporate Governance terhadap Audit Report Lag. Skripsi Universitas Dipenogoro.

Widya, Maria Graffeliesta. 2013. Pengaruh Karakteristik Komite Audit Terhadap Audit Report Lag (Studi Empiris Pada Perusahaan NonFinancial Yang Terdaftar Di Bursa Efek Indonesia). Skripsi Universitas Dipenogoro.

Wijaya, Aditya Taruna. 2012. Pengaruh Karakteristik Komite Audit Terhadap Audit Report Lag (Kajian Empiris Pada Perusahaan Yang Terdaftar Di Bursa Efek Indonesia Tahun 2010). Skripsi Universitas Dipenogoro.

Wikipedia. 2014. Indeks Kompas 100.

https://id.wikipedia.org/wiki/Indeks Kompas100, diakses pada tanggal 22 Maret 2017.

www.idx.co.id. Diakses pada tanggal 15 Januari 2017.

Zattoni, A. and Cuomo, F. 2010. How independent, competent and incentivized should non-executive directors be? An empirical examination of good corporate codes. British Journal of Management, 21 (1): 63-79.

\section{Lampiran 1 Sampel Penelitian}


Bq. Anggun HL, Bambang, E Yana Yuliana: Pengaruh Good Corporate Governance...

\begin{tabular}{|c|c|c|}
\hline No & Kode & Nama Perusahaan \\
\hline 1 & AALI & Astra Agro Lestari Tbk \\
\hline 2 & ACES & Ace Hardware Indonesia Tbk \\
\hline 3 & ADHI & Adhi Karya (Persero) Tbk \\
\hline 4 & ADRO & Adaro Energy Tbk \\
\hline 5 & AISA & Tiga Pilar Sejahtera Food Tbk \\
\hline 6 & AKRA & AKR Corporindo Tbk \\
\hline 7 & ANTM & Aneka Tambang (Persero) Tbk \\
\hline 8 & APLN & Agung Podomoro Land Tbk \\
\hline 9 & ASII & Astra International Tbk \\
\hline 10 & ASRI & Alam Sutera Realty Tbk \\
\hline 11 & BBCA & Bank Central Asia Tbk \\
\hline 12 & BBNI & Bank Negara Indonesia (Persero) Tbk \\
\hline 13 & BBRI & Bank Rakyat Indonesia (Persero) Tbk \\
\hline 14 & BBTN & Bank Tabungan Negara (Persero) Tbk \\
\hline 16 & BDMN & Bank Danamon Tbk \\
\hline 17 & BEST & Bekasi Fajar Industrial Estate Tbk \\
\hline 18 & BHIT & MNC Investama Tbk \\
\hline 19 & BJBR & BPD Jawa Barat \& Banten \\
\hline 20 & BJTM & BPD Jawa Timur Tbk \\
\hline 21 & BMRI & Bank Mandiri (Persero) Tbk \\
\hline 22 & BMTR & Global Mediacom Tbk \\
\hline 23 & BSDE & Bumi Serpong Damai Tbk \\
\hline 24 & BWPT & BW Plantation Tbk \\
\hline 25 & CPIN & Charoen Pokphand Indonesia Tbk \\
\hline 26 & CTRA & Ciputra Development Tbk \\
\hline 27 & CTRP & Ciputra Property Tbk \\
\hline 28 & DILD & Intiland Development Tbk \\
\hline 29 & DOID & Delta Dunia Makmur Tbk \\
\hline 30 & ELSA & Elnusa Tbk \\
\hline 31 & $\mathrm{EXCL}$ & XL Axiata Tbk \\
\hline 32 & GGRM & Gudang Garam Tbk \\
\hline 33 & GJTL & Gajah Tunggal Tbk \\
\hline 34 & ICBP & Indofood CBP Sukses Makmur Tbk \\
\hline 35 & INCO & Vale Indonesia Tbk \\
\hline 36 & INDF & Indofood Sukses Makmur Tbk \\
\hline 37 & INTP & Indocement Tungqal Prakasa Tbk \\
\hline 38 & ISAT & Indosat Tbk \\
\hline
\end{tabular}




\begin{tabular}{|c|c|c|}
\hline No & Kode & Nama Perusahaan \\
\hline 39 & ITMG & Indo Tambangraya Megah Tbk \\
\hline 40 & JPFA & Japfa Comfeed Indonesia Tbk \\
\hline 41 & JSMR & Jasa Marga (Persero) Tbk \\
\hline 42 & KIJA & Kawasan Industri Jababeka Tbk \\
\hline 43 & KLBF & Kalbe Farma Tbk \\
\hline 44 & LPCK & Lippo Cikarang Tbk \\
\hline 45 & LPKR & Lippo Karawaci Tbk \\
\hline 46 & LPPF & Matahari Department Store Tbk \\
\hline 47 & LSIP & PP London Sumatera Indonesia Tbk \\
\hline 48 & MAPI & Mitra Adiperkasa Tbk \\
\hline 49 & MDLN & Modernland Realty Ltd Tbk \\
\hline 50 & MEDC & Medco Energi Internasional Tbk \\
\hline 51 & META & Nusantara Infrastructure Tbk \\
\hline 52 & MLPL & Multipolar Tbk \\
\hline 53 & MNCN & Media Nusantara Citra Tbk \\
\hline 54 & MPPA & Matahari Putra Prima Tbk \\
\hline 55 & NIRO & Nirvana Development Tbk \\
\hline 56 & PGAS & Perusahaan Gas Negara (Persero) Tbk \\
\hline 57 & PNBN & Bank Pan Indonesia Tbk \\
\hline 58 & PNLF & Panin Financial Tbk \\
\hline 59 & PTBA & Bukit Asam (Persero) Tbk \\
\hline 60 & PTPP & Pembangunan Perumahan (Persero) Tbk \\
\hline 61 & PWON & Pakuwon Jati Tbk \\
\hline 62 & RALS & Ramayana Lestari Sentosa Tbk \\
\hline 63 & SAME & Sarana Meditama Metropolitan Tbk \\
\hline 64 & SCMA & Surya Citra Media Tbk \\
\hline 65 & SIDO & Industri Farmasi dan Jamu Sido Muncul Tbk \\
\hline 66 & SILO & Siloam International Hospitals Tbk \\
\hline 67 & SIMP & Salim Ivomas Tbk \\
\hline 68 & SMBR & Semen Baturaja (Persero) Tbk \\
\hline 69 & SMCB & Holcim Indonesia Tbk \\
\hline 70 & SMGR & Semen Indonesia (Persero) Tbk \\
\hline 71 & SMRA & Summarecon Agung Tbk \\
\hline 72 & SRIL & Sri Rejeki Isman Tbk \\
\hline 73 & SSIA & Surya Semesta Internusa Tbk \\
\hline 74 & SSMS & Sawit Sumbermas Sarana Tbk \\
\hline 75 & TAXI & Express Transindo Utama Tbk \\
\hline 76 & TBIG & Tower Bersama Infrastructure Tbk \\
\hline
\end{tabular}


Bq. Anggun HL, Bambang, \& Yana Yuliana: Pengaruh Good Corporate Governance...

\begin{tabular}{|r|c|l|}
\hline \multicolumn{1}{l|l}{ No } & \multicolumn{1}{l|}{ Kode } & Nama Perusahaan \\
\hline 77 & TINS & Timah (Persero) Tbk \\
\hline 78 & TLKM & Telekomunikasi Indonesia (Persero) Tbk \\
\hline 79 & TMPI & PT Sigmagold Inti Perkasa Tbk \\
\hline 80 & TOTL & Total Bangun Persada Tbk \\
\hline 81 & UNTR & United Tractors Tbk \\
\hline 82 & UNVR & Unilever Indonesia Tbk \\
\hline 83 & WIKA & Wijaya Karya (Persero) Tbk \\
\hline 84 & WSKT & Waskita Karya (Persero) Tbk \\
\hline
\end{tabular}

Lampiran 2

Hasil Penelitian

Hasil Uji Koefisien Determinasi Regresi Berganda

\begin{tabular}{|l|l|r|r|r|r|}
\hline \multicolumn{7}{|c|}{ Model Summary } \\
\hline Model & $\mathrm{R}$ & $\mathrm{R}$ Square & $\begin{array}{c}\text { Adjusted R } \\
\text { Square }\end{array}$ & $\begin{array}{c}\text { Std. Error of } \\
\text { the Estimate }\end{array}$ & $\begin{array}{c}\text { Durbin- } \\
\text { Watson }\end{array}$ \\
\hline 1 & $.461^{\mathrm{a}}$ & .212 & .162 & 18.640 & 1.841 \\
\hline
\end{tabular}

a. Predictors: (Constant), KW, KI, KAP, DK, KA

a. Dependent Variable: ARL

Sumber: SPSS 16 (data sekunder diolah), 2017

Hasil Uji F Regresi Berganda

\begin{tabular}{|c|c|c|c|c|c|c|}
\hline \multicolumn{7}{|c|}{ ANOVA $^{\text {b }}$} \\
\hline \multicolumn{2}{|c|}{ Model } & $\begin{array}{l}\text { Sum of } \\
\text { Squares }\end{array}$ & $\mathrm{df}$ & $\begin{array}{l}\text { Mean } \\
\text { Square }\end{array}$ & $\mathrm{F}$ & Sig. \\
\hline \multirow[t]{3}{*}{1} & Regression & 7294.432 & 5 & 1458.886 & 4.199 & $.002^{\circ}$ \\
\hline & Residual & 27099.806 & 78 & 347.433 & & \\
\hline & Total & 34394.238 & 83 & & & \\
\hline
\end{tabular}

a. Predictors: (Constant), KW, KI, KAP, DK, KA

b. Dependent Variable: ARL 


\section{Hasil Uji t Regresi Berganda}

\begin{tabular}{|c|c|c|c|c|c|c|}
\hline \multicolumn{7}{|c|}{ Coefficients $^{\mathrm{a}}$} \\
\hline \multirow{2}{*}{\multicolumn{2}{|c|}{ Model }} & \multicolumn{2}{|c|}{$\begin{array}{l}\text { Unstandardized } \\
\text { Coefficients }\end{array}$} & \multirow{2}{*}{\begin{tabular}{c|} 
Standardized \\
Coefficients \\
Beta \\
\end{tabular}} & \multirow[b]{2}{*}{$\mathrm{t}$} & \multirow[b]{2}{*}{ Sig. } \\
\hline & & B & Std. Error & & & \\
\hline 1 & (Constant & 110.772 & 12.836 & & 8.630 & .000 \\
\hline & DK & -3.327 & 1.246 & -.288 & -2.670 & .009 \\
\hline & KI & -.261 & .175 & -.153 & -1.490 & .140 \\
\hline & KA & -3.511 & 3.234 & -.118 & -1.086 & .281 \\
\hline & KAP & 1.435 & 4.345 & .034 & .330 & .742 \\
\hline & KW & -9.231 & 4.171 & -.228 & -2.213 & .030 \\
\hline
\end{tabular}

a. Dependent Variable: ARL

Sumber: SPSS 16 (data sekunder diolah), 2017

Hasil Uji Koefisien Determinasi Regresi Moderat Model Summary ${ }^{\mathbf{b}}$

\begin{tabular}{|l|r|r|r|r|r|}
\hline Model & $\mathrm{R}$ & $\mathrm{R}$ Square & $\begin{array}{c}\text { Adjusted R } \\
\text { Square }\end{array}$ & $\begin{array}{l}\text { Std. Error of } \\
\text { the Estimate }\end{array}$ & $\begin{array}{l}\text { Durbin- } \\
\text { Watson }\end{array}$ \\
\hline 1 & $.488^{\mathrm{a}}$ & .238 & .146 & 18.814 & 1.936 \\
\hline
\end{tabular}

a. Predictors: (Constant), KWKAP, DK, KI, KWDK, KAP, KWKI, KA, KWKA, KW

a. Dependent Variable: ARL

Sumber: SPSS 16 (data sekunder diolah), 2017

Hasil Uji F Regresi Moderat

\begin{tabular}{|c|c|c|c|c|c|c|}
\hline \multicolumn{7}{|c|}{ ANOVA $^{\text {b }}$} \\
\hline \multicolumn{2}{|c|}{ Model } & $\begin{array}{l}\text { Sum of } \\
\text { Squares }\end{array}$ & df & $\begin{array}{l}\text { Mean } \\
\text { Square }\end{array}$ & $\mathrm{F}$ & Sig. \\
\hline 1 & Regression & 8200.186 & 9 & 911.132 & 2.574 & $.012^{\mathrm{a}}$ \\
\hline & Residual & 26194.052 & 74 & 353.974 & & \\
\hline & Total & 34394.238 & 83 & & & \\
\hline
\end{tabular}


a. Predictors: (Constant), KWKAP, DK, KI, KWDK, KAP, KWKI, KA, KWKA, KW

b. Dependent Variable: ARL

Sumber: SPSS 16 (data sekunder diolah), 2017

Hasil Uji t Regresi Moderat

Coefficients $^{\mathrm{a}}$

\begin{tabular}{|l|r|r|r|r|r|}
\hline \multirow{2}{*}{ Model } & \multicolumn{2}{|c|}{$\begin{array}{c}\text { Unstandardized } \\
\text { Coefficients }\end{array}$} & $\begin{array}{c}\text { Standardized } \\
\text { Coefficients }\end{array}$ & & \multirow{2}{*}{} \\
\cline { 2 - 4 } & \multicolumn{1}{|c|}{ B } & Std. Error & \multicolumn{1}{c|}{ Beta } & \multicolumn{1}{c|}{$\mathrm{t}$} & \multicolumn{1}{c|}{ Sig. } \\
\hline 1 (Constant) & 182.273 & 102.376 & & 1.780 & .079 \\
DK & -3.370 & 1.269 & -.292 & -2.655 & .010 \\
KI & -.235 & .190 & -.138 & -1.239 & .219 \\
KA & -4.230 & 3.454 & -.142 & -1.224 & .225 \\
KAP & 1.657 & 4.437 & .040 & .373 & .710 \\
KW & -12.333 & 6.433 & -.305 & -1.917 & .059 \\
KWDK & -12.441 & 28.720 & -.048 & -.433 & .666 \\
KWKI & -93.466 & 197.823 & -.076 & -.472 & .638 \\
KWKA & -29.775 & 26.128 & -.131 & -1.140 & .258 \\
KWKAP & -2.746 & 36.912 & -.008 & -.074 & .941 \\
\hline
\end{tabular}

a. Dependent Variable: ARL

Sumber: SPSS 16 (data sekunder diolah), 2017 